\title{
Island Ecological Tourism: Construction of Indicators of Tourist Service System of Penghu National Scenic Area
}

\author{
Chih Yu Hsiao ${ }^{1 *}$, Li Hao Chiang ${ }^{2}$, Chun Min Kuo ${ }^{3}$ and Chao Lin Tuan ${ }^{2}$ \\ 1 Department of Tropical Agriculture and International Cooperation, National Pingtung University of Science and \\ Technology; skybluesea2004@hotmail.com \\ 2 Department of Agribusiness Management, National Pingtung University of Science and Technology; \\ 3 Department of Leisure Industry Management, National Chin-Yi University of Technology; \\ * Correspondence: skybluesea2004@hotmail.com ; Tel.: +886-958607360
}

\begin{abstract}
In order to increase the number of tourism in ecotourism, enhance the ecotourism attractions. It is essential to construct the ecotourism service system for the Penghu National Scenic Area because the ecology system is sensitive and frangible. This study adopts the Fuzzy Delphi method and Analytic Hierarchy Process (AHP) to establish an index framework of ecotourism service system of Penghu National Scenic Area. The results indicated that there are 4 dimensions which include 21 factors service attributes are identified as the service system for traveling. The findings are concluded as follows:(1)the security management capability is the main principle for ecotourism service system;(2)the ecological diversity is fundamental for the marine environment and the core resource for ecotourism;(3)the transportation capacity and environmental quality need to improve; (4)the marine environmental resources is the most important item for sound ecotourism development; (5)the enhancement of the operation willingness of local communities can promote ecotourism development;(6)the natural resources should be protected to provide an ideal recreational environment for ecotourism;(7)the development of ecotourism needs to support local conservation to achieve sustainability. The perspectives of sustainability and service system are involved to support the value of this study, which can continuously sustain Penghu archipelago.
\end{abstract}

Keywords: Ecotourism, Sustainability, Island Tourism, Penghu National Scenic Area, Tourist Service System

\section{Introduction}

Ecotourism is one travel style of sustainable tourism which is growing development trend for recent years and contributing on the jobs and revenue obviously for the local community (World Tourism Organization; UNWTO, 2018). According to UNWTO forecast, an estimated 1.8 billion tourists around the world would be sustainable tourists (UNWTO, 2018). Meanwhile, face to the ongoing economic growth, the tourist's demand changing to multiple traveling styles such as ecotourism, green tourism, and ecotourism. Thus, the tourism industry needs to change the activities to meet the tourist's satisfaction and protect the natural resource [3]. Among the several approached elements to ecotourism as follow: First of all, depends on the good quality of natural resources, cultural heritage, and biodiversity. Second, involves in the community. Third, realizes the environmental awareness and cultural heritage. Fourth, upgrades the market growth of ecotourism [9, 32, 36, 41]. However, when analyzing the aforementioned elements, the good ecotourism features concerns arose: (a) based on the nature and culture; (b) focus on the environmental education; (c) realize the awareness of environmental protection; (d) shared benefit for the community and stakeholder; (e) constructed the relationship among environment, society, economic and tourists. [5, 7, 28, 36] It including the carrying capacity of the resources and provide the benefits for local community and industries [39]. Consequently, in order to keep the ecotourism sustainable development, it must undergo careful planning and management [1]. In addition, conducting the stakeholder's perspectives, (a) to fulfill tourist's satisfaction; (b) to connect with the local community, and (c) to use effectively local resources are crucial to achieving the goal of ecotourism sustainable development. 
The coastline of Penghu archipelago Islands is $448 \mathrm{~km}$ long, likes other forms of ecotourism, it has been one of the main sources of revenue as the Taiwanese government has been promoting tourism worldwide as a business. To date, there still have the numerous tourists with the multiple-day trip because of the transportation limited. In this regards, the Taiwanese Tourism Bureau (2017) announced the policy that points out "The Ecotourism Year" provide 42 ecological experience package tours including Penghu island ecological tours. [35] However, it takes more tourists to visit and grows up the revenue for local resident but also break the featured marine resource. Some practices focus on the part islands of Penghu archipelago area to discuss their ecotourism development from different perspectives. For the tourist's satisfaction, Liang and Tsai (2008) investigated 364 visitors that ecotourism motivation, experience activity have influence revisit intention [23]. Hsieh, Park, and Huh (2016) compared between local resident's and tourist's attitude to point out the positive economic and cultural resource will upgrade the tourism development [17]. Moreover, Chao and Chao (2017) argued Wang-An islands, known for valuable green turtle resource that discuss the visitors need to closely enhance the environmental concern, deep experience activities, and small-scale tours while the local resident needs to learn more about their environmental knowledge to become the interpreter [5]. For the local community, Yu, Chu, and Tsai (2011) argued that the local communities need to protect the environmental resource and increase deeply the tourist image [46]. Wu and Tsai (2015) point out the local community is the crucial element for the tourist's activities in the south part of the Penghu archipelago [43]. Thus, analyzing the aforementioned, most of the literature discusses the ecotourism development by the one islands, one perspective (e.g. tourist's satisfaction, local community, marine resource). Face the global trends and Taiwanese policy, this paper constructed sustainability and service system, which can continuously sustain Penghu archipelago.

This paper begins by describing the marine ecological resources; local community; operating system; tourist activities to construct the ecotourism service system, followed by discussing each criterion and indicators of the ecotourism service system. The service system is developed for this study, as well as the experimental result and conclusion are provided.

\section{Literature review}

\subsection{Penghu archipelago and tourism}

Island ecotourism is one of the important attractions of Penghu, which managed by Penghu National Scenic Area, known as the archipelago area of Taiwan. It has received destination recognition for its island ecotourism, which involved in fish, sea turtle, coral reef, intertidal zone, seashore plant ecology, migratory birds, and basalt cliff [5]. From May 2003, Penghu Fireworks Festival had held by Penghu county government, it became a magnet for tourists visiting Penghu. According to data released by the Penghu County Government Tourism Department, there have 736,268 tourists visited Penghu in 2016 notably 63.56\% engage in ecotourism including basalt cliff, intertidal zone, and seashore plant ecology.

Based on the Penghu archipelago, natural resource, and position, there is three ecotourism system as followed (Fig.1):

1. Magong ecotourism system: Most local resident in here, have deep Taiwanese culture, and basalt cliff. The economic, cultural and political center in Penghu as well.

2. Northern ecotourism system: consist of 7 islands have fish, coral reef, intertidal zone, seashore ecology, and migratory birds. Notably, Stone weirs in the famous destination.

3. Southern ecotourism: consist of 10 islands have fish, sea turtle, coral reef, basalt cliff. The green sea turtle is the most famous resource. 
With the rapid tourism development, excess tourist activities not only destroyed the island's ecosystem but debased the quality of ecotourism $[5,15,28,44]$. Thus, in order to sustainable ecotourism development, constructing the ecotourism service indicator system is very important. 

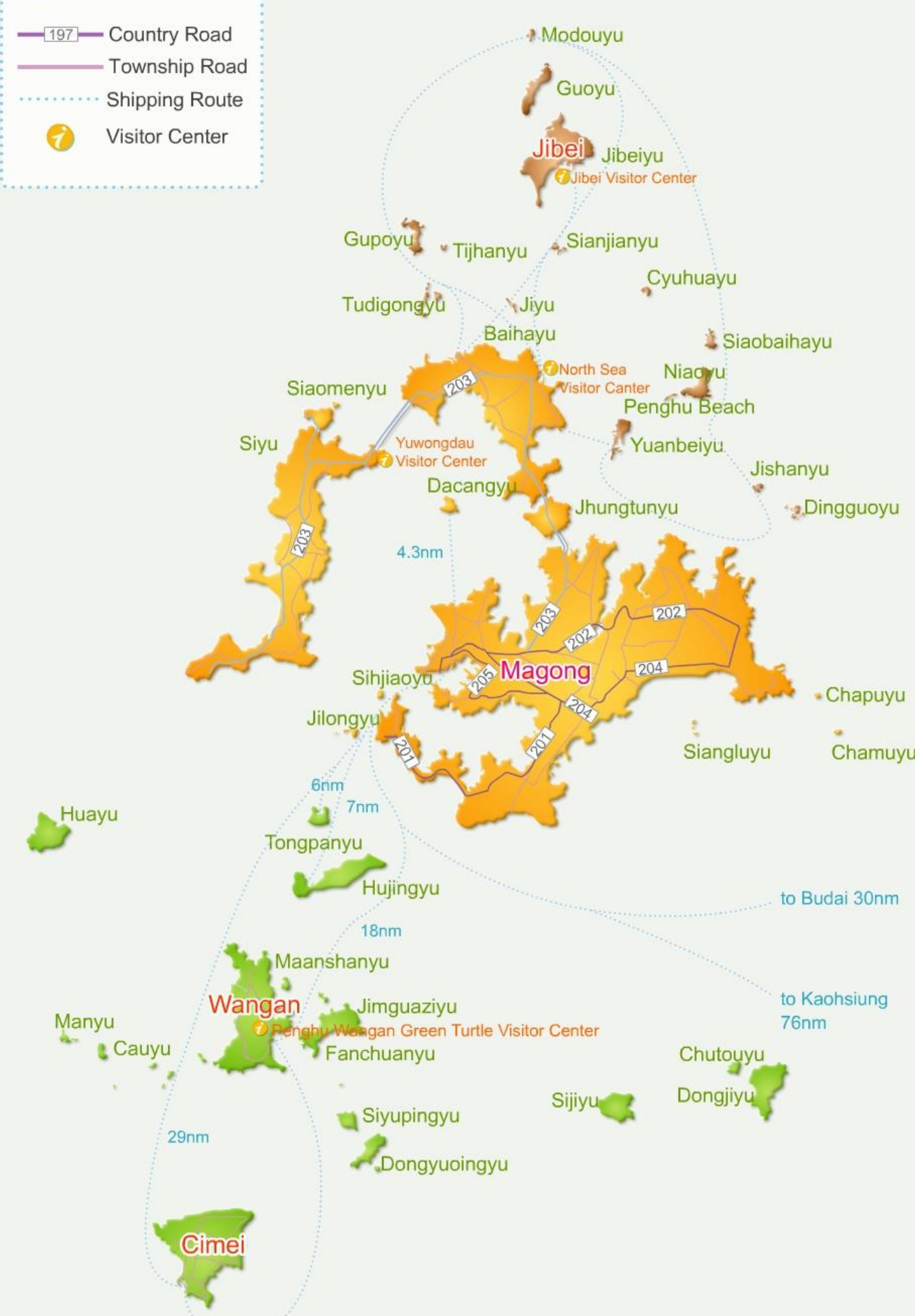

Fig. 1 The Map of Penghu National Scenic Area 


\subsection{Ecotourism and sustainable}

Ecotourism is a sustainable and responsible way of engaging in tourist's styles. It aims to protect the biodiversity, natural environment, historical and culture heritage. Through the tourist process, the tourists can establish the mission of the environment and realize the value of the ecological resource [24] . Miller and kaae [27] argued that two types ecotourism based on the responsible traveling continuum, one is called passive ecotourism, it expected to reduce the environmental impacts while providing the tourists with natural experiences; the other one is called active ecotourism, it limited the tourism activities cannot be permitted to produce the environmental impacts, and needed to focus on the environmental ethics. It needs to develop and manage such activities for tourist destinations which shall not sacrifice its resources - cultural or natural -in order to attain sustainability [3]. In order to reduce environmental impacts and enhance ecological efficiency, the local ecological resource and tourist activities will be considered. However, the local community or residents always neglected to evaluate the ecotourism development [26, 37]. Until now, some practice considered the factors of the local community on the ecotourism development [11, 18]. Das and Chatterjee (2015) [10] who argued that local communities receive low net benefits, and sometimes negative, from ecotourism activities.

Sustainable development has been applied to many fields, including tourism and community development, it refers that "meets the needs of the present without compromising the ability of future generations to meet their own needs." [40]. The UNWTO define the sustainable tourism as "meeting the needs of present tourists and host regions while protecting and enhancing opportunities for the future. It is envisaged as leading to management of all resources in such a way that economic, social and aesthetic needs can be fulfilled while maintaining cultural integrity, essential ecological processes, biological diversity, and life support systems.' [38] In terms of sustainable tourism involved in agri-tourism, green tourism, and ecotourism and has been determined by economic, social, community, cultural, environmental and institutional perspectives, with the goal of achieving long-term cooperation among stakeholders in protecting the ecosystem while promoting tourism [38]. [48] draw up the "International Year of Sustainable Tourism for Development" in 2017 and make the 17 indicators of Sustainable Development and the Sustainable Development Goals (SDGs) to evaluate the sustainable ecotourism among five categories as followed: (1) Inclusive and sustainable economic growth; (2) Social inclusiveness, employment and poverty reduction; (3)Resource efficiency, environmental protection and climate change; (4) Cultural values, diversity and heritage; (5)Mutual understanding, peace and security.

In short, [25] pointed out the four indicators to evaluate the ecotourism criteria involved in ecology, society, economic and regulation. [30] constructed the ecotourism criteria among tourist and community and ecological resource to evaluate the North Sulawesi scenic area in Indonesia and Amazonas in Brazil(Fig. 2). [34] used among the institution, local community, environment, and tourism industry to construct the ecotourism indicator. Thus, this paper will apply the [34] indicator to construct however ecotourism industry needs to face the tourist immediately, it also added the service system to discuss on the next part. 


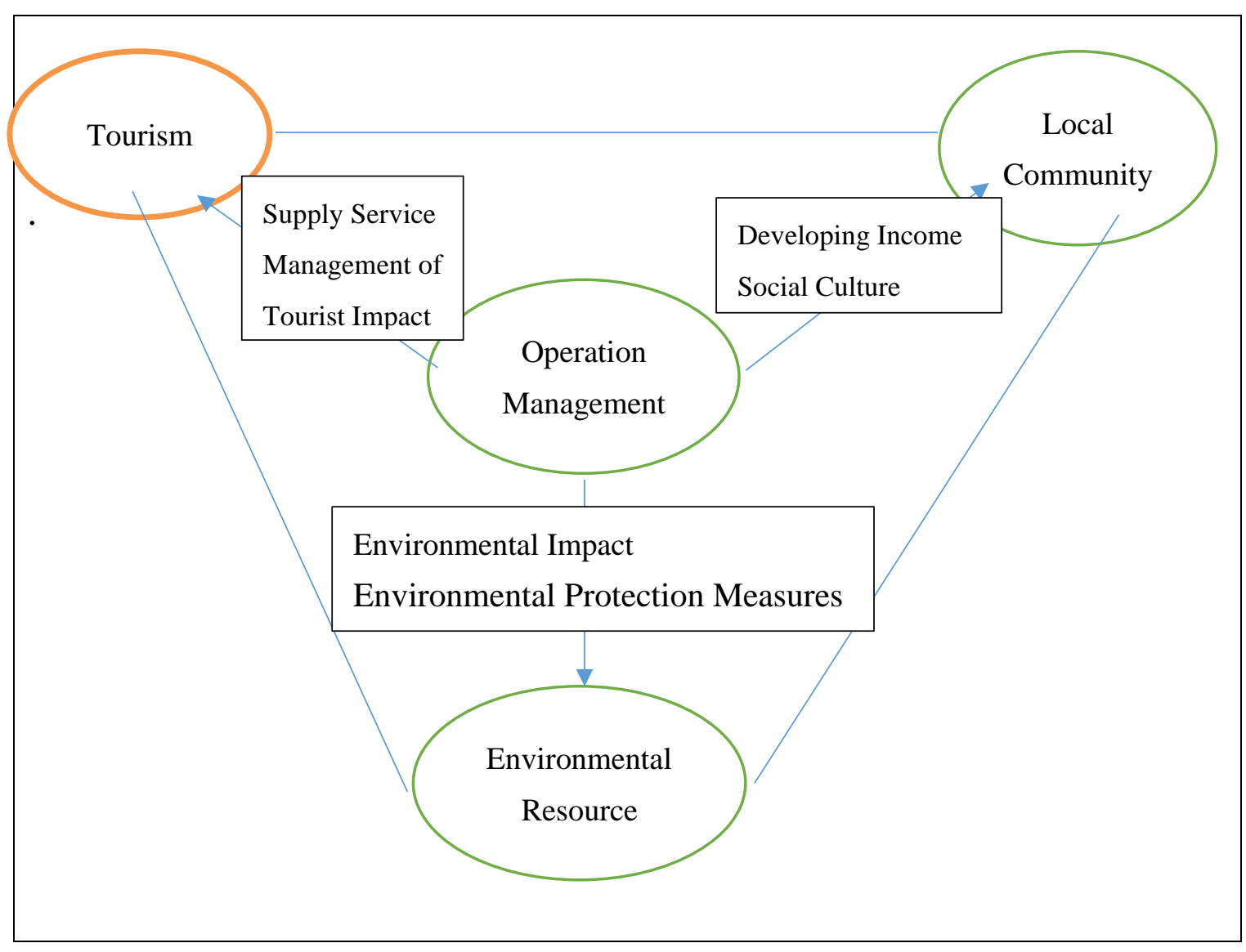

Fig. 2 Research Framework

\section{Service system}

In order to fulfill the tourist's satisfaction, service is very important factors in the trip. Service system which emphasizes the process during the service design to service completion and satisfied the customer demand. The service systems focus on the customer, activities, environment, technology, labor, and organization [8, 12] . [16] argued that three objectives to upgrade the quality of ecotourism service and satisfaction of tourists as followed; (a) environment, economic, and society, (b) service quality and labor training, (c) tourists safety protection and information safety which formulated the four indicators among (a) reduce the negative environmental resources, (b) decrease the social and cultural collapsed, (c) well use the local resource, and (d) quality management to improve the quality of ecotourism. [42] provide the eight indicators of the operating system to increase the ecotourism service system concerns raise; (a) Organization Management: to promote ecotourism planning, business management, environmental education, ecotourism. (b) Transportation System Management: to maintain the road and trail system, (c) Resource Maintenance Management: to protect the biological resource, water resources, (d) Facilities Maintenance Management; to maintain the infrastructure, (e) Environmental Management; to keep the environmental clean, (f) Interpretation Service Management: to ensure the interpretation location, to train the interpreter , (g) Tourist Safety Management: to ensure the tourist process safety, and (h) Financial Management: to balance the budget and make sure the benefit to stakeholder and community. Consequently, in order to fulfill tourist's satisfaction while considering the ecotourism feature, refer to the [42] service system indicator to apply to this paper.

In this work, constructed the service system of traveling, as aforementioned on ecotourism featured involved in an institution, local community, environment, and tourism industry, and tourist satisfaction. This research tries to combine between ecotourism system indicator [34] and service system indicator [42] to construct the 
service system of traveling in Penghu. On the previous study, [16] considered the improvement on the service quality and tourist satisfaction in Romania, using 4 indicators involve in decreasing the environmental pollution, improving the relationship on the local community, upgrading the efficient environment, and enhancing the quality of management.

\subsection{Fuzzy Delphi Method; (FDM)}

This research adopted the Delphi process to identify the service system of traveling indicators. Delphi has been widely used in numerous tourism domain works to achieve a consensus among a group of people to establish sustainable ecotourism indicators. The Fuzzy Delphi Method theory was developed by [49], it can address situations where humans cannot precisely describe. It is used to overcome shortcomings by avoiding the distortion of expert opinions, capturing the semantic structure of predicted items, and considering the fuzzy nature of the data gathering/interview process [22].

Constructing a service system of traveling into Penghu National Scenic Area, there is no consensus has been reached as to how each indicator counts the tributes to the goal of ecotourism in Penghu. [22] have employed a Delphi survey in which 13 experts assessed 143 indicators to measure the relative importance of each indicator. Thus, in order to assess the indicator on service system of traveling in Penghu, this paper employed a Fuzzy Delphi Method to conduct with the expert feedback.

\subsection{Analytic Hierarchy Process;(AHP)}

Analytic Hierarchy Process was structured by [31] is a decision-making process which handling complex decision problems. It established a hierarchical structure to simplify the evaluation process and constructed the pair-wise comparison matrix to indicate the relative importance of alternatives and finally calculated the priority weights of alternatives according to the pairwise comparison matrix. However, the AHP method has some shortcoming in the decision-making process. In the light of this, [4] argued that fuzzy Analytic Hierarchy Process (FAHP) combine the fuzzy theory and AHP to improve the decision-making process. [29] used the fuzzy AHP to obtain the sustainable ecotourism indicator in Philippine. [47] determine the tourist activities on ecotourism by fuzzy AHP.

This study obtained consensus through the brainstorming of a panel of experts and then used an expert questionnaire survey to develop the hierarchical structure and to calculate the weight of various critical factors affecting service system of traveling in Penghu. This study used various evaluation dimensions and the weight of evaluation indices to understand the relationship among various critical factors and their importance.

\section{Materials and Methods}

\subsection{Survey questionnaire}

Twelve members were selected on the first round of Fuzzy Delphi Method from three categories: 4 academic scholars; 4 senior ecotourism industry managers in Penghu, and 4 officers in the Penghu government bureaus and the second round of AHP method total 18 members were selected from the preface mentioned, the three groups have 6 members respectively. The first stage expert questionnaire survey was conducted from April 12, 2016, to April, 25; the second stage conducted from April 27, 2016, to May 13, 2016.

\subsection{Research Framework}

For the purpose of this paper to construct the service system of traveling in Penghu. According to the literature, Penghu is the island ecotourism area and managed by Penghu Scenic Area. [30] used the tourism, local community and environmental resource to construct the indicator on the service system of ecotourism. [34] argued that operating management also have the influence to provide the positive ecotourism activities and the organization target need to change in the "customer- orientation." [42]

3.3Identification of service system of traveling indicator 
Conducting the literature review and considering the Penghu resource, local community, tourism industry, and Penghu tourism bureau. This paper conducts the first level of the target is ecological tourist's service system which is included four dimensions of level 2 which is the marine environmental resource, local community, operating system, and island tourist activity and there are 24 indicators in level 3 (See Table 1). In terms of marine environmental resource refer Bio-diversity, Resources in substitutability, Resources Rareness, Ecological Originality, Ecological Suitability, and Environmental Protection [30, 34, 35, 38]. The operation aspiration, Community and resource co-prosperity, growing revenue and feedback fund to the community, stabilize and developing the community may be assessed to in terms of local community [30,34, 43]. According [42]considered the indicator of the service system and Penghu characteristic involved in island-to-island communication, traffic transportation, safety management, environmental quality, interpretation quality, and service quality may be conducted in terms of operating system. For tourist's activities assessed to six indicators involved in tourist expectation and satisfaction, participate in conservation proactively, industry and conservation co-prosperity, tourism comprehensive, tourism industrial Corporate Social Responsibility (CSR).

In this research, Buckley's FAHP is used to find the fuzzy weights. It is both easy to implement and reliable. The procedure can be summarized as follows: The decision makers' opinions about importance weights of criteria and sub-criteria are pulled using pair-wise comparisons. During the FAHP process, this research distinguished the criteria (or sub-criteria) in cumulative frequency distribution function which involved acceptable respectively maximum (F1(x)) and minimum (F2(x)) of indicator identity. Second, calculating the value of the first quartile, median and third quartile in F1(x) and F2(x) and named the (C1, M1, D1); (C2, M2, $\mathrm{D} 2)$ respectively. Finally, combine the $(\mathrm{C} 1, \mathrm{D} 1)$ and $(\mathrm{C} 2, \mathrm{D} 2)$ to measure the importance of criteria $\left(\mathrm{X}^{*}\right)$. The linguistic scale and corresponding triangular fuzzy numbers $\left(\mathrm{C} 1, \mathrm{M} 1, \mathrm{X}^{*}\right)$ are: Just equal $(1,1,1)$, Equally important $(1,1,3)$, Weakly important $(1,3,5)$, Essentially important $(3,5,7)$, Very strong important $(5,7,9)$, Absolutely important $(7,9,9)$. The threshold value needs to reach 7 or higher to the indicator $[4,31]$.

The results show in Table.1, safety management and bio-diversity get 9 scores (absolutely important indicator), in contrast, Ecological Suitability (6.5), developing the community (5.0), and tourist expectation (6.5) was removed because the indicator is lower than the threshold value of consensus in the second rounds of fuzzy Delphi survey. 
Table.1 Evaluating secondary factor pointers triangular fuzzy functions

\begin{tabular}{|c|c|c|c|c|c|c|c|}
\hline $\begin{array}{l}\text { Target } \\
\text { (level } \\
1 \text { ) }\end{array}$ & $\begin{array}{l}\text { Dimension } \\
\text { (level } 2 \text { ) }\end{array}$ & $\begin{array}{l}\text { Factors } \\
\text { (level } 2 \text { ) }\end{array}$ & C1 & $\mathrm{C} 2$ & D1 & D2 & $X^{*}$ \\
\hline \multirow{9}{*}{ 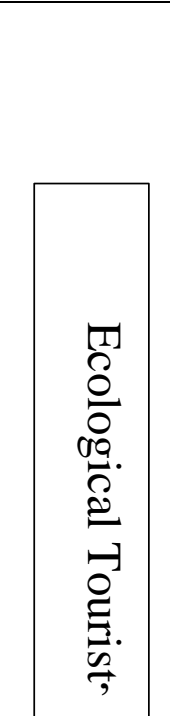 } & \multirow{6}{*}{$\begin{array}{l}\quad \text { Marine } \\
\text { environmental } \\
\text { resource }\end{array}$} & Bio-diversity & 9 & 8 & 7 & 9 & 9 \\
\hline & & $\begin{array}{c}\text { Resources } \\
\text { substitutability }\end{array}$ & 7 & 9 & 5 & 7 & 7 \\
\hline & & Resources Rareness & 7 & 9 & 5 & 8 & 7.5 \\
\hline & & $\begin{array}{l}\text { Ecological } \\
\text { Originality, }\end{array}$ & 8 & 6 & 7 & 9 & 8.5 \\
\hline & & Ecological suitability & 6 & 8 & 4 & 7 & 6.5 \\
\hline & & $\begin{array}{l}\text { Environmental } \\
\text { protection }\end{array}$ & 7 & 10 & 5 & 8 & 7.5 \\
\hline & \multirow{6}{*}{$\begin{array}{c}\text { Local } \\
\text { community }\end{array}$} & $\begin{array}{cc}\text { The } & \text { operation } \\
\text { aspiration } & \end{array}$ & 8 & 9 & 6 & 9 & 8.5 \\
\hline & & $\begin{array}{l}\text { Community and } \\
\text { resource co-prosperity }\end{array}$ & 6 & 9 & 5 & 8 & 7 \\
\hline & & $\begin{array}{l}\text { Feedback fund to the } \\
\text { community }\end{array}$ & 6 & 10 & 5 & 9 & 7.5 \\
\hline \multirow{15}{*}{ 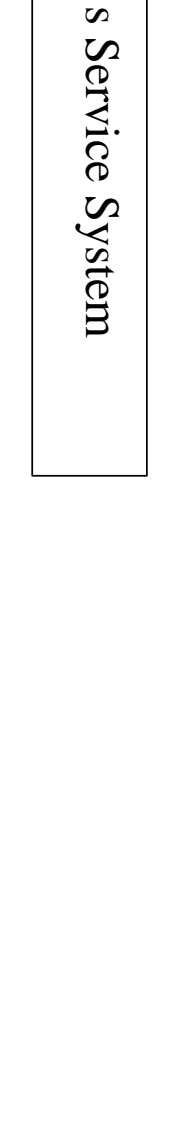 } & & Growing revenue & 7 & 9 & 4 & 7 & 7 \\
\hline & & Community, stabilize & 7 & 9 & 6 & 8 & 7.5 \\
\hline & & $\begin{array}{l}\text { Developing the } \\
\text { community }\end{array}$ & 5 & 8 & 4 & 5 & 5 \\
\hline & \multirow{6}{*}{$\begin{array}{l}\text { Operating } \\
\text { system }\end{array}$} & $\begin{array}{l}\text { Island-to-island } \\
\text { communication }\end{array}$ & 7 & 9 & 3 & 7 & 7 \\
\hline & & $\begin{array}{l}\text { Traffic } \\
\text { transportation, }\end{array}$ & 8 & 9 & 6 & 9 & 8.5 \\
\hline & & Safety management & 9 & 9 & 7 & 9 & 9 \\
\hline & & $\begin{array}{l}\text { Environmental } \\
\text { quality }\end{array}$ & 8 & 9 & 7 & 9 & 8.5 \\
\hline & & Interpretation quality & 7 & 9 & 6 & 8 & 7.5 \\
\hline & & Service quality & 8 & 9 & 6 & 9 & 8.5 \\
\hline & \multirow{6}{*}{$\begin{array}{l}\text { Island } \\
\text { tourist activity }\end{array}$} & Tourist expectation & 6 & 9 & 4 & 7 & 6.5 \\
\hline & & Tourist satisfaction & 8 & 6 & 7 & 9 & 8.5 \\
\hline & & $\begin{array}{l}\text { Participate in } \\
\text { conservation proactively }\end{array}$ & 6 & 9 & 5 & 9 & 7.5 \\
\hline & & $\begin{array}{lr}\quad \text { Industry } & \text { and } \\
\text { conservation } & \text { co- } \\
\text { prosperity } & \\
\end{array}$ & 7 & 9 & 5 & 8 & 7.5 \\
\hline & & $\begin{array}{c}\text { Tourism } \\
\text { comprehensive, }\end{array}$ & 8 & 9 & 6 & 8 & 8 \\
\hline & & $\begin{array}{l}\text { Tourism industrial } \\
\text { social responsibility }\end{array}$ & 7 & 8 & 3 & 7 & 7 \\
\hline
\end{tabular}

At level 2, the purpose of this study to construct the service system of traveling in Penghu to evaluate the marine environmental resource, local community, operating system, and island tourist activity. The first hierarchical model has constructed the service system of traveling in Penghu at the top level. At the first level, the weights were determined the marine environmental resource, local community, operating system, and island tourist activity by four dimensions. The results show the Table 2, the first dimension is a marine environmental resource (0.449), operating system (0.253), local community (0.150), island tourist activity (0.148). 
Table 2. Analysis of the relative important dimension in the level 2

\begin{tabular}{|l|l|l|}
\hline $\begin{array}{c}\text { Ecological Tourist's Service System in } \\
\text { Penghu National Scenic Area }\end{array}$ & Weight & Ranking \\
\hline Marine environmental resource dimension & 0.449 & 1 \\
\hline Local community dimension & 0.150 & 3 \\
\hline Operating system dimension & 0.253 & 2 \\
\hline Island tourist activity dimension & 0.148 & 4 \\
\hline C.R. (Consistency ratio) & 0.011 & \\
\hline C.I. (Consistency index) & 0.010 & C.R. $\times$ R.I. \\
\hline$\lambda$ Amax & 4.031 & M + C.I $\times(\mathrm{m}-1)]$ \\
\hline Remark :C.I =0.010 < 0.1,means Indicates a consistent of overall judgment; C.R $=0.011<0.1$, \\
means the consistency of the display matrix is satisfactory
\end{tabular}

At level 3, because of the fuzzy Delphi survey, Ecological Suitability, developing the community, and tourist expectation was removed. Total 21 indicators divided into a marine environmental resource (5 indicators), local community (5 indicators), operating system (6 indicators), and island tourist activity (5 indicators) (See table 3). In all, the relative weight of these indicators was determined by using consistency to ensure the reliability of the results. On the other hand, the weights of each indicator in the hierarchical model were calculated pair-wise comparisons.

Table 3. The different level weight ratio of ecosystem service system in Penghu National Scenic Area

\begin{tabular}{|c|c|c|c|}
\hline Target & $\begin{array}{l}\text { Weight of } \\
\text { dimension } \\
\text { (a) }\end{array}$ & $\begin{array}{l}\text { Weight of Factor } \\
\text { (b) }\end{array}$ & $\begin{array}{l}\text { Weight } \\
(\text { a) } \times(\text { b) }\end{array}$ \\
\hline \multirow{21}{*}{$\begin{array}{l}\text { Ecological } \\
\text { Tourist's } \\
\text { Service } \\
\text { System }\end{array}$} & \multirow{5}{*}{$\begin{array}{l}\text { Marine } \\
\text { environme } \\
\text { ntal } \\
\text { resource } \\
(0.449) \\
\end{array}$} & Bio-diversity $(0.266)$ & 0.119 \\
\hline & & Resources substitutability $(0.152)$ & 0.068 \\
\hline & & Resources rareness $(0.193)$ & 0.087 \\
\hline & & Ecological originality $(0.181)$ & 0.081 \\
\hline & & Environmental protection $(0.208)$ & 0.093 \\
\hline & \multirow{5}{*}{$\begin{array}{l}\text { Local } \\
\text { community } \\
(0.150)\end{array}$} & The operation aspiration $(0.318)$ & 0.048 \\
\hline & & Community and resource co-prosperity $(0.287)$ & 0.043 \\
\hline & & Feedback fund to the community $(0.155)$ & 0.023 \\
\hline & & Growing revenue( 0.105$)$ & 0.016 \\
\hline & & Community, stabilize $(0.135)$ & 0.020 \\
\hline & \multirow{6}{*}{$\begin{array}{l}\text { Operating } \\
\text { system } \\
(0.253)\end{array}$} & Island-to-island communication (0.060) & 0.015 \\
\hline & & Traffic transportation $(0.192)$ & 0.049 \\
\hline & & Safety management(0.227) & 0.057 \\
\hline & & Environmental quality(0.254) & 0.064 \\
\hline & & Interpretation quality $(0.117)$ & 0.030 \\
\hline & & Service quality $(0.150)$ & 0.038 \\
\hline & \multirow{5}{*}{$\begin{array}{l}\text { Island } \\
\text { tourist } \\
\text { activity } \\
(0.148)\end{array}$} & Tourist satisfaction $(0.089)$ & 0.013 \\
\hline & & Participate in conservation proactively $(0.226)$ & 0.034 \\
\hline & & Industry and conservation co-prosperity $(0.356)$ & 0.053 \\
\hline & & Tourism comprehensive $(0.183)$ & 0.027 \\
\hline & & Tourism industrial social responsthe ibility(0.146) & 0.022 \\
\hline
\end{tabular}

\section{Results and Disscussion}

For the fuzzy Delphi survey, all of the experts consider the safety management and bio-diversity were absolutely important indicators. [13] argued that the tourists selected the destination the prior 
considerable reason is safety. The good safety management can get the tourist activities well and make the good tourism developing [6, 17] . [45] followed the previous study to construct the safety management in Penghu tourist. [28] conducted the Tioman Island in Malaysia, illustrating the most important factor is bio-diversity.

The weights of an indicator of tourist service system in Penghu were determined using the AHP with 18 experts. The relative weights of three levels of four dimensions and 21 indicators were calculated. This paper combined the weights between the second level and third level. The results show the bio-diversity (0.119) had the highest weight among environmental protection (0.093), Resources Rareness (0.087), and Ecological Originality (0.081), Resources Insubstitutability (0.068) assess in terms of marine environmental resource. Ecotourism in nature-based tourism, [39] make the key success factor on the east java island in Indonesia, the prior factor is a marine environmental resource. [46] argued that protect the marine resource have the positive developing of tourism. [5] provide the resident need to protect the local environment to get more revenue.

The lowest weight indicator was tourist satisfaction (0.013), island-to-island communication (0.015), growing revenue to the community $(0.016)$, stabilize community $(0.020)$, tourism industrial Corporate Social Responsibility (0.022). [5] investigated the resident and visitor perceptions of WAAn islands (Green sea turtle), pointed out the gap between visitor and resident, the local resident cannot provide the tourist product or service to fulfill visitor. For island-to-island communication, island resource can share with others island, each island can combine other islands to set the multiple-day tours, design long-term travel to attract [36]. For the growing revenue to the community and stabilize the community, [38] make the SDGs criteria to measure the sustainable tourism focus on the economic growth in the local community. [20] pointed out the ecotourism provide the jobs and growing revenue in the community. [5]pointed out the local resident need to understand their environmental resource in detail to get the additional revenue. [28] conducted the Tioman island in Malaysia, argued that tourism CSR needs to improve to bring the tourists perception of environmental protection.

For the local community, the highest weight was operation aspiration (0.048) and Community and resource co-prosperity (0.043). [21] illustrated the operation aspiration and enhance the community and resource co-prosperity can bring up the local resident to conserve also upgrade the environmental quality, revitalize the old structure and conserve their local culture [38]. In addition, for the operating system, the environmental quality $(0.064)$ ranked first, safety management $(0.057)$ and traffic transportation (0.049). [9] investigated the eco-tourist and point out the good environmental quality lead to ecotourism activities. Thus, a good ecotourism landscape needs to maintain the environmental quality [7]. [24] point out the good traffic transportation is key factors on ecotourism the tourist activities. Moreover, for the island tourist activities, industry and conservation co-prosperity (0.053). [5] point out the local resident participation is a key important factor, upgrading the participation aspiration of the local resident can grow up the economy.

\section{Managerial implication}

5.1Attached the importance to Bio-diversity that improve the quality of the marine resource

For island ecotourism sustainable development, Bio-diversity is the important factor [19]. [2] argued that the resource had a positive influence on community and tourism in Kenyir island.[6] argued the bio-diversity is the most important factor for coastal ecotourism which applied the Fuzzy Delphi method to evaluate. To address the conservation of the marine resource, the environmental friendly traveling style reduced the conflict of ecotourism. The tourists need a stronger environmental commitment to visit such as smaller scale traveling and local environmental experience activities deeply and carry toiletries by yourself [5]. On the other hand, the stakeholder and local resident need to improve the local environmental protection awareness and knowledge affected the tourists.

5.2 Promoted the participation of stakeholder and local community increase the depth of eco-tourism 
The local community, stakeholder, and tourist have interactive during the ecotourism involved in experience activity, interpretation, and sightseeing to get the benefit. Therefore, the willingness to participate in the community has a considerable influence on eco-tourism. The community can closely integrate tourism development with community development and environmental protection, and at the same time protect the resources and promote the economic development of the community $[3,5,14]$.

5.3 Safety management is the core factor in ecotourism sustainable development

Ecotourism is highly interactive between the local community and tourist. In order to fulfill the tourist safety satisfaction. [45] construct the safety management indicators in Penghu island that argued the traffic safety, recreational safety, accommodation safety, sanitary safety and shopping safety. Thus, to ensure the safety in Penghu, the local community need to consider five aspects, the natural safety to prevent the disaster of climate change. Second, the biological safety to avoid the toxic plant and animals. Thirdly, unplanned the steep slope, narrow road and cliff. Fourth, maintain the facility safety and training the local resident and tourist safety knowledge.

\subsection{Environmental conservation is the guideline of tourist activity}

Ecotourism sustainable development based on the natural resource. For local resident need to have environmental concern and awareness knowledge to find the balance between the tourist and local surrounding. [14] argued that use the resource to develop the ecotourism which can bring the economic benefit for local resident and promote the environmental concern. More local residents try to find many ways such as Ecological Capacity, Physical Capacity, Facility Capacity, and Social Capacity to standardize the tourist [33] that conserve the environment to develop.

5.5 The government need to support local resource inventory and provide the guideline of marine resource protection

The government should be able to support local resource inventor, and divide ecotourism into core protected areas, buffer recreational areas and intensive recreation areas according to the degree of protection, reduce the impact of tourists on environmental impacts, and assist in the restoration of the damaged natural ecological environment and provide visitors to get a high-quality traveling.

In addition, the government should consider maintenance, restraint, binding, participation, and active policy support to implement environmental monitoring mechanisms to avoid degradation or even deterioration of biodiversity, and strengthen the promotion of marine ecological engineering methods. [39] argued that the government needs to provide the guide for the stakeholder in carrying out their marine resource. The increase of marine biodiversity and the establishment of measures to protect marine resources will under strict environmental and standard norms, help the industry to maximize its economic, social and environmental benefits in the process of creating a sustainable development of ecotourism.

5.6 Encourage local communities to promote ecotourism

Ecotourism development attaches great importance to local communities, emphasizing the participation of local communities in planning and management. Local communities are the key factors among protection, economic benefits and social benefits [21]. The government should actively encourage and strengthen the counseling strategy. By establishing a business license, contracting of protection and cooperation, support the stable development of ecotourism in local communities, and achieve the concept of ecotourism respecting nature and the attitude of local residents.

5.7Constructing a specific normative plan for the ecotourism promotion service system

The government should formulate a clear and specific management mechanism for ecotourism development, provide operators to follow, and measure the environment, society, economy, and culture to maximize the benefits.

The government should strengthen environmental quality management practices to reduce marine drifting waste as a priority and provide the necessary facilities for tourists, such as accommodation and catering facilities, water supply and power supply facilities, Telecommunications facilities, public toilet facilities. In addition, Penghu ecotourism has rich in natural resources, and more unsafe factors than the general scenic spots. Therefore, the concern and 
practice of ecotourism for safety management is a responsibility. The government should take the basic core resources of ecotourism as a starting point for thinking and create a complete safety management system that includes integrated prevention work, rescue work, and after-care work. The transportation capacity of the Penghu National Scenic Area is very inconvenient, the bus schedule is very rare, and the information is not easy to obtain, especially for maritime transportation. Many islands can only choose to take private transportation, and they need to match the package traveling. It seems that it is not in line with international standards. The government should make public shipping classes to provide local residents and tourists to choose, and make information on transportation services, that tourists can easily to find. In short, aforementioned that provides the necessary elements for successful ecotourism management. [48] applied the service quality models to ecotourism in Malaysia, which argued that need to refine the service system model when used in different contexts.

Ecotourism requires many stakeholders to coordinate and cooperate, using natural resources and environmental resources, and designing experience traveling through recreational resources to attract tourists to meet the needs of recreation. The local resource can develop the featured experience activities by ecotourism tour and make the subjectivity of ecotourism prominent in Penghu National Scenic Area.

\section{References}

1. Baral, N. (2015). Assessing the temporal stability of the ecotourism evaluation scale: testing the role and value of replication studies as a reliable management tool," Journal of Sustainable Tourism, 23, 2, 280-293.

2. Bhuiyan, Md, Chamhuri, S., \& Mohamad Ismail, S. (2015) Sustainability measurement for ecotourism destination in Malaysia: A study on Lake Kenyir, Terengganu, Social Indicators Research, 128(3).

3. Blancas, F. J., Lozano-Oyola, M. \& González, M. (2015). A European sustainable tourism labels proposal using a composite indicator. Environmental Impact Assessment Review, 54, 39-54.

4. Buckley, J.J. (1985). Ranking alternatives using fuzzy numbers, Fuzzy Sets Systems, 15(1), 21-31.

5. Chao, Y. L., \& Chao, S.Y. (2017). Resident and visitor perceptions of island tourism: Green sea turtle ecotourism in Penghu Archipelago, Taiwan. Island Studies Journal, 12(2), 213-228.

6. Chang, Y. C., \& Wu, C. H. (2014) Evaluation indicators for coastal ecotourism based on Fuzzy Delphi method, Journal of Taiwan Agricultural Engineering, 60(2), 10-20.

7. Chen, H. S. (2015). The establishment and application of environment sustainability evaluation indicators for ecotourism environments. Sustainability. 7, 4727-4746.

8. Chen, T. Y. (2010). Service Management 3rd edition. Taipei: Hwa Tai Publishing.

9. Chiu, Y. T., Lee, W. I., \& Chen, T. H. (2014). Environmentally responsible behavior in ecotourism: antecedents and implications. Tourism Management, 40, 321-329.

10. Das, M. \& Chatterjee, B. (2015) Ecotourism and empowerment: A case analysis of Bhitarkanika Wildlife sanctuary, Odisha, India, IIM Kozhikode Society \& Management Review, 4(2),136-145

11. Gezon, L. L. (2014) Who wins and who loses? Unpacking the local people concept in ecotourism: a longitudinal study of community equity in Ankarana, Madagascar. Journal of Sustainable Tourism,. 22(5), 821-838.

12. Glynn, W. J., \& Barnes, J. B. (1995). Understanding Services Management. Ireland: John Wiley \& Sons, Inc.

13. Hauber, A. R., \& Zandbergen, A. G. A. (1996). Foreign visitors as targets of crime in the Netherlands: Perceptions and actual victimization over the years 1989, 1990, and 1993. Security Journal, 7, 211-218.

14. Hayes, M. C., Peterson, M. N., Justa L. H-K., \& Langerhans. R. B.. (2015). Tourism-related drivers of support for protection of fisheries resources on Andros Island, The Bahamas. Ocean \& Coastal Management, 118123.

15. Hillery, M., Nancarrow, B., Griffin, G., \& Syme, G. (2001). Tourist perception of environmental impact. Annals of Tourism Research, 28(4), 853-867.

16. Hornoiu, R.I., Minciu, R. \& Hociung, I.G. (2009). Methods and indicators regarding the tourism assessment impact in protected areas, (University of Messina \& Bucharest Academy of Economic Studies) The 2009 International Conference on Tourism, Messina, Italy 22-25 April, Messina. 
17. Hsieh, C. M., Park, S. H. \& Huh, C. (2016). A comparison model of residents' and tourists' attitudes toward sustainable tourism development: A case of Penghu island in Taiwan. Tourism Travel and Research Association: Advancing Tourism Research Globally, 11.

18. Hunt, C. A., Durham, W. H., Driscoll, L., \& Honey, M. (2015) Can ecotourism deliver real economic, social, and environmental benefits? A study of the Osa Peninsula, Costa Rica, Journal of Sustainable Tourism, 339357.

19. Hunt, C. \& Vargas, E. (2018). Turtles, tacos, and tourists: protected areas and marine turtle conservation in Costa Rica. Journal of Park and Recreation Administration, 36, 101-114.

20. Kontogeorgopoulos, N., \& Chulikavit, K. (2010). Supply-side perspectives on ecotourism in Northerland Thailand. International Journal of Tourism Research, 12,627-647.

21. Kutay, K. (1991). Cahuita national park, Costa Rica : A case study in living cultures and national park management, In Resident People and National Parks: Social Dilemmas and Strategies in International, Tucson: University of Arizona Press.

22. Lee, T. H., \& Hsieh, H. P. (2016). Indicators of sustainable tourism: A case study from a Taiwan's wetland. Ecological Indicators, 67, 779-787.

23. Liang, C. H., \& Tsai, C. Y. (2008). A study of relationships among tourist motivation, experience, satisfaction and revisiting intention of Penghu ecotourism. Journal of Sport and Recreation Research, 2(3), 94-109.

24. Lin, F. L. (2008). The tour planning for the sustainable ecotourism in the Green island of Taiwan, master thesis, Taiwan.

25. Marsh, H. W. (1993) The effects of participation in sport during the last two years of high school, Sociology of Sport Journal, 10,18-43.

26. Mathis, A. \& Rose, J. (2016) Balancing tourism, conservation, and development: a political ecology of ecotourism on the Galapagos Islands, Journal of Ecotourism, 64-77.

27. Miller, M.L. \& Kaae, B.C. (1993). Coastal and marine ecotourism: A formula for sustainable development? Trends, 30(2), 35-41.

28. Ng, S. I., Chia, K. W., Ho, J. A., \& Ramachandran, S.. (2017). Seeking tourism sustainability - A case study of Tioman Island, Malaysia. Tourism Management. 58, C, 101-107.

29. Ocampo, L., Ebisa, J. A., Ombe, J., \& Geen Escoto, M. (2018). Sustainable ecotourism indicators with the Fuzzy Delphi method - A Philippine perspective, Ecological Indicators, 93,874-888.

30. Ross, S. \& Wall, G. (1999). Evaluating ecotourism: The case of North Sulawesi, Indonesia. Tourism Management, 20, 673-682.

31. Saaty, T. L. (1980). The Analytic Hierarchy Process, New York: McGraw-Hill.

32. Shelly, R. \& Wall, G. (2001). Evaluating ecotourism: The case North Sulawesi. Annual Tourism Research, 23(1), 122-132.

33. Shelby, B., \& Heberlein, T.A. (1984) A conceptual framework for carrying capacity determination. Leisure Sciences, 6, 433-451

34. Sung, R. (2003). Multiple analysis of ecotourism. Journal of Beijing International Studies University, 3, 33 38.

35. Taiwanese Tourism Bureau., Republic of China. (2018). Yearly report of tourism statistics. Available online: http://admin.taiwan.net.tw/statistics/year_en.aspx?no=15 (assessed on 10 July, 2018)

36. Tuan, C. L. (2016). Recreational agriculture: An Experience Respective. Taipei: Farseeing published.

37. Thompson, B. S., Gillen, J., \& Friess, D. A. (2018) Challenging the principles of ecotourism: insights from entrepreneurs on environmental and economic sustainability in Langkawi, Malaysia, Journal of Sustainable Tourism, 257-276.

38. United Nations World Tourism Organization (UNWTO) (2018). Tourism in the 2030 Agenda. Available online: http://www2.unwto.org/content/tourism-2030-agenda (assessed on 15 June, 2018)

39. Wardani, M. P., Fahrudin, A., \& Yulianda, F. (2017). Analysis of successful strategy to develop sustainable marine ecotourism in Gili Bawean Island, Gresik, East Java. Earth and environmental science, 89.

40. World Commission on Environment and Development (1987) Our Common Future. New York: Oxford.

41. Weaver, D.B. \& Lawton, L.J. (2007). Twenty years on: The state of contemporary ecotourism research. Tourism Management, 28, 1168-1179.

42. Weng, L. S. (2014). Development of Taiwan Forest Recreation Area operation service system. Taiwan Forestry Journal, 40(1), 69-76. 
43. Wu, C.C., \& Tsai, H.M. (2015). A capital-based framework for assessing coastal and marine social-ecological dynamics and natural resource management: A case study of Penghu archipelago. Journal of Marine and Island Cultures, 3(2), 60-80.

44. Wu, H. C., Huang, C. T., \& Hung, C. M. (2005). Residents' perceptions of ecotourism and attitudes toward its development in the Pescadores, Taiwan, Journal of outdoor recreation study, 18(3), 1-30.

45. Wang, M. Q. (2015) Research of tourism safety management strategies on Penghu county - application of analytic hierarchy process (AHP), Master Thesis, National Sun Yat-sen University, Kaohsiung.

46. Yu, S. L., Chu, Y. C., \& Tsai, C. W. (2015). Stone weirs in Penghu and adaption to tourism development. Journal of Ecology and Environment, 38(2), 257-262.

47. Yılmaz, H , \& Surat, H . (2015). Analitik hiyerarşi süreci kullanılarak en uygun ekoturizm etkinliğinin belirlenmesi. Turkish Journal of Forestry, 16 (2), 164-176.

48. Yusof, N., Abd Rahman, F., Che Jamil, M. F., \& Mohammad, I.. (2014) Measuring the quality of ecotourism services: Case study-based model validation, SAGE, 4(2), 1-9.

49. Zadeh, L. A. (1965). Fuzzy sets, Information and Control, 8(3), 338-353. 